\title{
Perancangan Visualisasi Dashboard dan Clustering dengan Menerapkan Business Intelligence pada Dinas DPMPTSP Kabupaten Dharmasraya
}

\author{
Ricky Akbar" ${ }^{\# 1}$, Mutia Octaviany ${ }^{\# 2}$ \\ \#Jurusan Sistem Informasi Fakultas Teknologi Informasi Universitas Andalas \\ Kampus Unand Limau Manis Padang - Sumatera Barat \\ ${ }^{1}$ rickyakbareit.unand.ac.id \\ ${ }^{2}$ mutyaoctaviany@gmail.com
}

\begin{abstract}
Abstrak - Penelitian ini bertujuan untuk merancang dan membangun dashboard dan clustering data layanan perizinan publik Dinas Penanaman Modal dan Pelayanan Terpadu Satu Pintu (DPMPTSP) Kabupaten Dharmasraya, untuk memudahkan proses analisis data dan pengambilan keputusan oleh pihak manajemen dengan memanfaatkan Business Intelligence. Karena selama ini proses analisis data masih dilakukan secara konvensional yaitu dengan mengambil data dari Aplikasi kemudian dikonversikan ke Microsoft Excel terlebih dahulu, baru dilakukan analisis. Proses seperti ini akan memakan waktu yang lama dan hasil analisis yang tidak akurat. Dalam melakukan Layanan Perizinan untuk Publik, Dinas DPMPTSP selama ini sudah menggunakan Aplikasi SiCantik, yaitu aplikasi berbasis web yang terintegrasi untuk pengelolaan perizinan usaha maupun layanan umum lainnya yang bersifat Online Single Submission (OSS). Namun, aplikasi ini hanya sebatas melakukan pengelolaan data, belum terdapat visualisasi dashboard untuk memudahkan proses analisis. Sebelum melakukan perancangan dashboard dan proses clustering data, terlebih dahulu dilakukan pengolahan data dari Database Aplikasi dalam bentuk Extract-Transform-Load (ETL) menggunakan tool perangkat lunak Pentaho Data Integration (PDI), sedangkan untuk merancang dashboard dan proses clustering menggunakan perangkat lunak Mirosoft Power BI. Hasil dari penelitian ini adalah bentuk visualisasi dashboard yang interaktif dan mudah dipahami, serta pengelompokkan data dalam bentuk grafik clusterisasi yang dapat mempermudah pihak manajemen dalam pengambilan keputusan.
\end{abstract}

Kata kunci- Business Intelligence, Visualisasi, Clustering, Dashboard, DPMTSP Kabupaten Dharmasraya

\section{Pendahuluan}

Dinas Penanaman Modal dan Pelayanan Terpadu Satu Pintu (DMPTSP) adalah sebuah instansi pemerintah di Kabupaten Dharmasraya yang telah menerapkan pelayanan saling terintegrasi satu dengan yang lainnya. Melalui Dinas ini pemerintah dapat memberikan pelayanan terpadu, sehingga masyarakat dan dunia usaha mendapatkan kemudahan dalam melakukan pengurusan surat perizinan atau layanan umum lainnya. Dengan begitu tentunya dapat meningkatkan minat dan partisipasi masyarakat untuk mau menanamkan modal usahanya atau berinvestasi di daerah [1].

Dalam melakukan operasionalnya, dinas ini telah menggunakan sebuah perangkat lunak dengan nama "SiCantik" (Aplikasi Cerdas Layanan Perizinan Terintegrasi untuk Publik). Aplikasi ini berbasis komputasi awan yang bisa digunakan secara gratis oleh Dinas DPMPTSP. Perangkat lunak ini menggunakan platform Web Base yang terintegrasi, dan bersifat Online Single Submission (OSS) yang dapat difungsikan untuk memproses pengelolaan perizinan usaha maupun layanan umum lainnya pada DPMPTSP [2].

Akan tetapi, dalam melakukan analisis data, DPMPTSP belum menerapkan Visualisasi Dashboard yang dapat memberikan kemudahan pada proses analisis tersebut, karena masih dikerjakan secara konvensional atau manual, yaitu dengan menarik atau mengambil data melalui aplikasi SiCantik, kemudian data diolah terlebih dahulu menggunakan Microsoft Excel, setelah itu baru dilakukan proses analisis. Informasi yang diperoleh melalui cara seperti ini tentunya butuh waktu yang lama dan adanya ketidakakuratan data dari hasil analisisnya, sehingga nantinya dapat mempengaruhi kinerja pelayanan pada Dinas DPMPTSP Kabupaten Dharmasraya, serta proses pengambilan keputusan tidak sesuai dengan semestinya. Berdasarkan permasalahan ini, penerapan Business Intelligence (BI) dapat dijadikan sebagai salah satu solusi yang di usulkan pada Dinas DPMPTSP. "BI dapat meliputi perolehan data dan informasi dari berbagai sumber yang bervariasi dan mengolahnya dalam pengambilan keputusan" [3] Data yang pada awalnya hanya memiliki informasi tertentu saja, sekarang dapat di sampaikan banyak informasi penting secara langsung [4]

Business Intelligence (BI) merupakan suatu bentuk dari penerapan Teknologi Informasi, dalam menganalisis berbagai permasalahan dan dapat digunakan untuk mempermudah proses pengambilan keputusan [5] 
Menurut Howard Drenser BI adalah "seperangkat metode dan konsep yang berfungsi untuk meningkatkan kemampuan membuat keputusan dengan bantuan system yang berlandaskan pada fakta-fakta yang terjadi" [6]. Terdapat 6 komponen utama pada arsitektur BI, yaitu [7] : 1). Sumber Data, merupakan proses untuk menghimpun data dari berbagai sumber yang berasal dari penyimpanan operasional system; 2). Gudang Data, tahapan penggunaan ETL (Extract-Transform-Load) pada proses ini, yaitu mengumpulkan, mem-filter, dan melakukan pengolahan data yang tersimpan dalam berbagai sumber pada data warehouse [8][9][10]; 3). Eksplorasi Data, proses ini merupakan tahap penggunaan berbagai tools untuk keperluan analisis BI antara lain query, reporting system dan statitiscal method; 4). Penambangan Data, tahap ini terdiri dari sejumlah metodologi BI dengan tujuan mendapatkan pengetahuan dan informasi dari data tersebut; 5). Optimasi, tahapan ini menghasilkan solusi alternatif, kemudian akan dipilih solusi terbaik; 6). Keputusan, tahap ini adalah penentuan dalam pengambilan keputusan akhir yang akan diambil (Decisions Making Process).

Dengan diterapkannya BI pada Dinas DPMPTSP ini, diharapkan pengolahan data perizinan yang dilakukan pada proses analisis dapat ditingkatkan melalui perancangan visualisasi dashboard, dan clustering data. Sebelum melakukan perancangan visualisasi dashboard dan clustering, maka terlebih dahulu dilakukan proses pengolahan data dalam bentuk ETL dengan menggunakan tool Pentaho Data Integration (PDI), sedangkan untuk proses perancangan visualisasi dashboarddan clustering menggunakan perangkat lunak Microsoft Power BI. Hasil perancangan visualisasi ini nantinya berupa interaktif dashboard system yang mudah dipahami, Adapun visualisasi dashboard yang dihasilkan antara lain yaitu 1). Dashboard informasi layanan perizinan; 2). Dashboard informasi data investasi layanan perizinan; 3). Dashboard sebaran lokasi perusahaan layanan perizinan dan 4). Dashboard berupa clustering data perizinan. Sedangkan pada proses clusterisasi data dapat menghasilkan grafik berupa pengelompokan data yang mempunyai kemiripan. Untuk melakukan perancangan visualisasi dan clustering ini, digunakan data investasi pada Dinas DPMPTSP dari tahun 2016 sampai 2018, serta data bidang usaha dan sebaran lokasi data perizinan dikelompokkan berdasarkan tingkat kemiripannya. Hasil pengelompokan ini dapat digunakan untuk mendukung kebutuhan informasi yang diperlukan oleh berbagai bidang yang ada pada Dinas DPMPTSP seperti bidang perizinan, bidang pengembangan investasi serta bidang perencanaan dan promosi penanaman modal, dalam upaya untuk meningkatkan efektifitas promosi dan kualitas pelayanan penanaman modal.

\section{Metodologi}

\section{A. Metode Pengumpulan Data}

Metode pengumpulan data yang dilakukan pada penelitian ini adalah dengan studi literatur dan studi lapangan. Studi lapangan terdiri dari observasi, wawancara dan analisis dokumen.

\section{B. Metode Perancangan Dashboard}

Untuk proses perancangan visualisasi dashboard dan clustering pada DPMPTSP mengacu kepada Business Intelligence Road Map, yang dijadikan sebagai metode atau tahapannya. Road Map BI ini dapat dilihat gambar 1. [12]

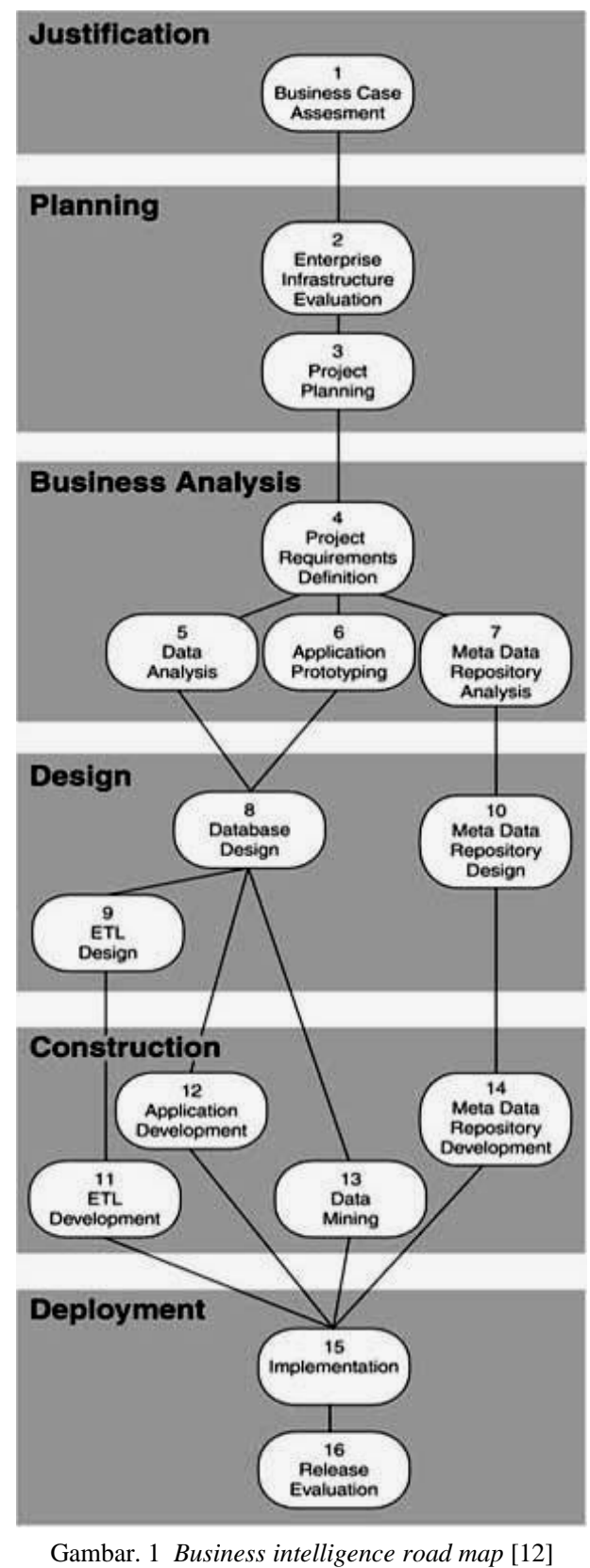

Berdasarkan gambar 1 terlihat bahwa Roadmap BI terdiri dari 6 tahapan yakni tahap "justification, planning, business analysis, design, construction dan deployment”, namun penelitian ini hanya menggunakan 5 tahapan saja tidak sampai ke tahap deployment, berikut uraiannya : 
1) Tahap Justification: Proses yang dilakukan pada tahapan ini adalah mengevaluasi kebutuhan BI pada DPMPTSP Kabupaten Dharmasraya dengan melakukan identifikasi terahdap berbagai permasalahan yang akan dipilih untuk penelitian.

2) Tahap Planning: Pada tahapan Planning ini dilakukan proses pengembangan terhadap rencana strategis terkait bagaimana melakukan perancangan proyek BI ini. Perencanaan proyek meliputi penggunaan teknologi dan tools yang dibutuhkan. Pada tahapan planning didapatkan output berupa perencanaan tools yang digunakan yaitu Pentaho Data Integration dan perangkat lunak Microsoft Power BI

3) Tahap Business Analysis: Proses pada tahapan ini adalah melakukan analisis yang lebih detail dalam upaya mendapatkan pemahaman yang lebih dalam terhadap sumber data dan kebutuhan informasi oleh DPMPTSP Kabupaten Dharmasraya.

4) Tahap Design: Tahapan ini merupakan proses untuk melakukan perancangan Data Warehouse dan proses ETL. Perancangan Data Warehouse ini berupa pembuatan tabel yang terdiri dari tabel fakta dan tabel dimensi. Perancangan proses ETL berupa gambaran pembuatan proses ETL yang mengikuti rancangan Data Warehouse yang telah dibuat sebelumnya. Proses perancangan Data Warehouse digunakan untuk melakukan penyimpanan data, visualisasi, dan clustering.
5) Tahap Construction: Tahapan akhir yang dilakukan dalam proses ini adalah konstruksi, yaitu membangun Data Warehouse pada database MySQL, setelah itu proses instalasi perangkat lunak BI yang akan diperlukan nantinya untuk proses ETL. Proses ETL dikerjakan mengikuti bentuk seperti merancang Data Warehouse, agar luaran yang dihasilkan selaras dengan masukan dalam membangun Dashboard. Kemudian baru dilakukan pembangunan Dashboard menggunakan aplikasi Power BI Desktop.

\section{HASIL DAN PEMBAHASAN}

Pada tahapan ini diuraikan hasil dan pembahasan yang prosesnya meliputi analisis data dan perancangan, pemodelan Data Warehouse Dimensional, Proses ETL, Penerapan Power Bi untuk Visualisasi Dashboard dan Visualisasi Clustering.

\section{A. Analisis Data dan Perancangan}

Pada bagian ini dilakukan analisis sumber data yang digunakan dan kebutuhan informasi dalam melakukan perancangan dan pembuatan Data Warehouse melalui proses ETL menggunakan tool PDI.

1) Analisis Sumber Data dan Informasi: Sumber Data yang digunakan dalam perancangan Data Warehouse yaitu data perizinan yang diambil dari Aplikasi SiCantik pada DPMPTSP dari tahun 2016 sampai tahun 2018. Sumber Data merupakan data perizinan yang telah diekspor ke dalam Microsoft Excel. Potongan Sumber Data ini dapat dilihat pada gambar 2 .

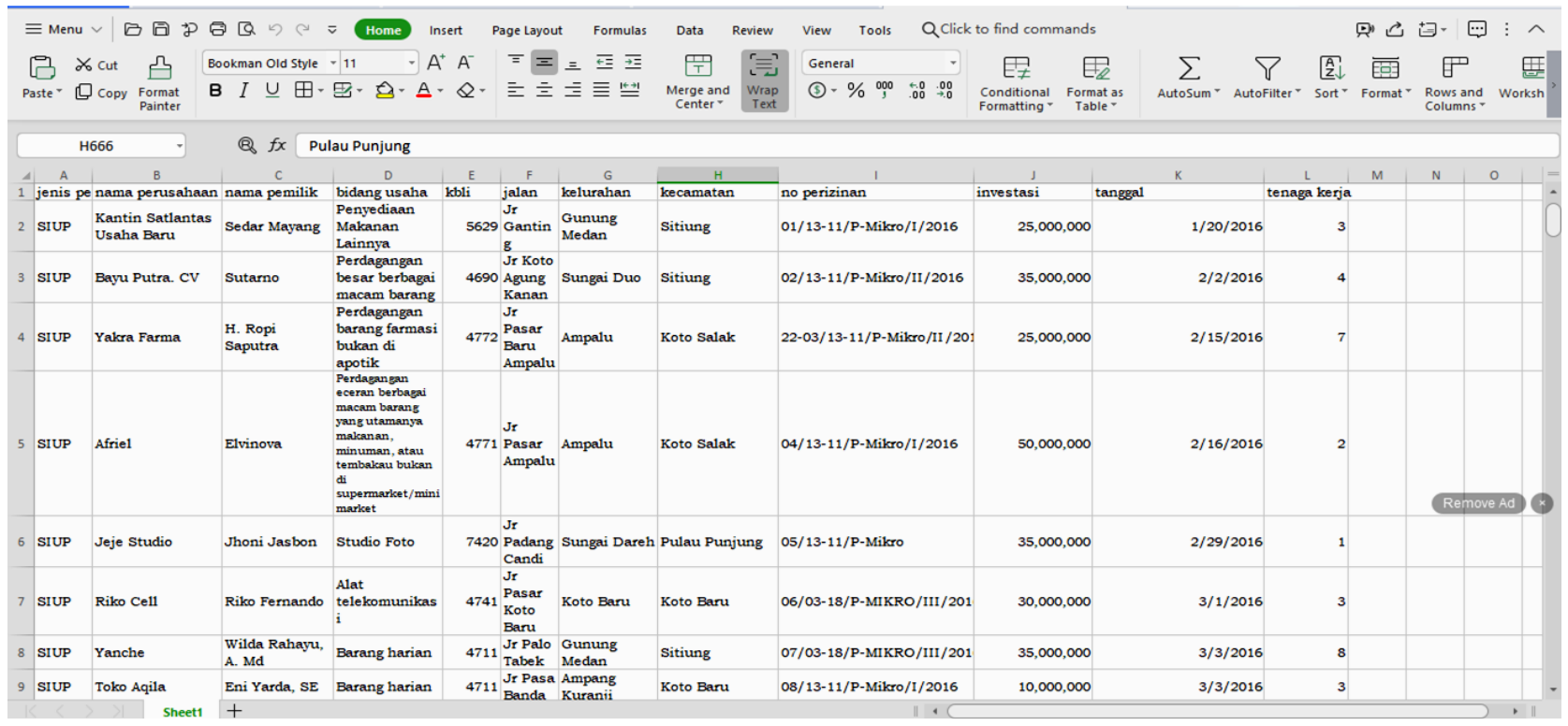

Gambar 2. Sumber data

Analisis kebutuhan informasi menggunakan metode wawancara dan observasi mengenai sistem yang telah ada. Berdasarkan hasil kedua metode tersebut, maka dapat di uraikan beberapa kebutuhan informasi yang diperlukan yaitu:

- Informasi total jumlah perizinan dari tahun 2016-2018
- Informasi total jenis perizinan

- Informasi total bidang usaha

- Informasi jumlah perizinan per tahun

- Informasi jumlah perizinan berdasarkan jenis perizinan

- Top 10 bidang usaha berdasarkan jumlah perizinan

- Informasi jumlah investasi pertahun 
- Informasi jumlah investasi berdasarkan kecamatan

- Informasi jumlah investasi berdasarkan jenis perizinan

- 5 investasi terbesar berdasarkan bidang usaha

- Informasi jumlah kecamatan

- Peta sebaran jumlah perizinan berdasarkan kecamatan

- Informasi total jumlah perizinan per kecamatan

- Informasi jumlah perzinan per kecamatan berdasarkan jenisperizinan

- Top 5 kecamatan berdasarkan jumlah perizinan

- Clustering data investasi pada kecamatan

- Clustering data investasi pada bidang usaha

\section{2) Perancangan Data Warehouse}

\section{a) Logical Architecture}

Proses pada arsitektur logikal ini diawali dari pengambilan data pada sumber data. Kemudian dilakukan proses ETL (Extract Transform Loading) sehingga menjadi data mart. Setelah itu baru dilakukan proses perancangan visualisasi dashboard. Arsitektur logikal ini terlihat pada gambar 3 .

\begin{tabular}{|c|c|c|c|}
\hline \multicolumn{4}{|c|}{ Arsitektur Logical DataMart } \\
\hline Data Source & Proses ETL & Data Mart & Visualisasi \\
\hline excel & $\begin{array}{l}\text { 1. Extract Data } \\
\text { 2. Transform Data } \\
\text { 3. Load Data }\end{array}$ & Data Mart & $\begin{array}{l}\text { Visuolizotion } \\
\text { Dashabord }\end{array}$ \\
\hline
\end{tabular}

Gambar 3. Logical architecture data warehouse

\section{b) Physical Architecture}

Proses yang terjadi pada arsitektur fisik dimulai dengan menstransformasikan data sumber dari database ke MS Excel. Kemudian dilakukan proses ETL menggunakan tool Pentaho Data Integration (PDI) sehingga menjadi data mart. Setelah itu dilakukan perancangan visualisasi data menggunakan aplikasi MS Power BI. Proses perancangan arsitektur fisik ini dapat dilihat pada gambar 4

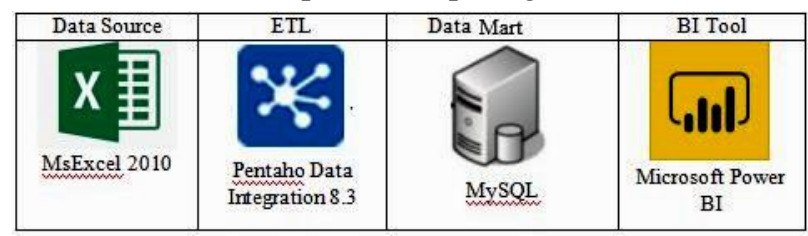

Gambar 4. Physical architecture data warehouse

\section{B. Pemodelan Data Warehouse Dimensional}

Pemodelan data dimensional merupakan proses identifikasi dan perancangan skema Data Warehouse yang telah dibuat. Tahapan dalam melakukan perancangan Data Warehouse ini menggunakan langkah-langkah yang ada metode Kimbal, yang terdiri atas 9 tahapan, sehingga dikenal dengan istilah nine step methodology. Kesembilan tahapan itu adalah "pemilihan proses, pemilihan grain, identifikasi dan penyesuaian, pemilihan fakta, penyimpanan pre-calculation di tabel, memastikan tabel dimensi, pemeliharaan durasi database, melacak perubahan dari dimensi secara perlahan, dan menentukan prioritas" [13]. Sedangkan Skema Data Warehouse yang digunakan adalah Star Scheme, skema yang menghubungkan secara langsung tabel dimensi ke tabel fakta dengan satu tabel fakta memiliki relasi minimal dengan satu tabel dimensi [14].

Sebelum menentukan Tabel Fakta dan Tabel Dimensi, maka terlebih dahulu dilakukan proses Pemilihan Grain. Grain adalah representasi dari informasi oleh setiap baris dari tabel fakta. Tujuan dilakukannya pemilihan Grain yaitu untuk menentukan baris apa saja yang ditampilkan dari tabel fakta dalam Data Warehouse. Grain yang dipilih dalam kasus ini dapat dilihat pada table 1 .

TABEL I

PEMILIHAN GRAIN

\begin{tabular}{|c|c|c|c|c|c|}
\hline \multirow[t]{2}{*}{ Grain } & \multicolumn{5}{|c|}{ Dimensi } \\
\hline & $\begin{array}{l}\text { Jenis } \\
\text { Periz } \\
\text { inan }\end{array}$ & $\begin{array}{l}\text { Pe } \\
\text { mil } \\
\text { ik }\end{array}$ & $\begin{array}{l}\text { Bid } \\
\text { ang } \\
\text { Usa } \\
\text { ha }\end{array}$ & $\begin{array}{l}\text { Wa } \\
\text { ktu }\end{array}$ & $\begin{array}{c}\text { Lok } \\
\text { asi }\end{array}$ \\
\hline $\begin{array}{lr}5 \text { investasi } & \text { terbesar } \\
\text { berdasarkan } & \text { bidang } \\
\text { usaha } & \end{array}$ & & & $\checkmark$ & & \\
\hline $\begin{array}{l}\text { Informasi jumlah } \\
\text { kecamatan }\end{array}$ & & & & & $\checkmark$ \\
\hline $\begin{array}{l}\text { Peta sebaran jumlah } \\
\text { perizinan berdasarkan } \\
\text { kecamatan }\end{array}$ & & & & & $\checkmark$ \\
\hline \begin{tabular}{lr} 
Informasi & jumlah \\
perzinan & per \\
kecamatan berdasarkan \\
\multicolumn{2}{l}{ jenis perizinan }
\end{tabular} & $\checkmark$ & & & & $\checkmark$ \\
\hline $\begin{array}{lr}\text { Top } \quad 5 & \text { kecamatan } \\
\text { berdasarkan } & \text { jumlah } \\
\text { perizinan } & \end{array}$ & & & & & $\checkmark$ \\
\hline $\begin{array}{lr}\text { Clustering } & \text { data } \\
\text { investasi } & \text { pada } \\
\text { kecamatan } & \end{array}$ & & & & & $\checkmark$ \\
\hline $\begin{array}{lr}\text { Clustering } & \text { data } \\
\text { investasi pada bidang } \\
\text { usaha }\end{array}$ & & & $\checkmark$ & & \\
\hline $\begin{array}{l}\text { Informasi jumlah } \\
\text { perizinan berdasarkan } \\
\text { jenis perizinan }\end{array}$ & $\checkmark$ & & & & \\
\hline $\begin{array}{l}\text { Top } 10 \text { bidang usaha } \\
\text { berdasarkan jumlah } \\
\text { perizinan }\end{array}$ & & & $\checkmark$ & & \\
\hline $\begin{array}{l}\text { Informasi total jumlah } \\
\text { perizinan dari tahun } \\
2016-2018\end{array}$ & & $\checkmark$ & & & \\
\hline $\begin{array}{l}\text { Informasi total jenis } \\
\text { perizinan }\end{array}$ & $\checkmark$ & & & & \\
\hline $\begin{array}{l}\text { Informasi total bidang } \\
\text { usaha }\end{array}$ & & & $\checkmark$ & & \\
\hline $\begin{array}{l}\text { Informasi jumlah } \\
\text { perizinan per tahun }\end{array}$ & & & & $\checkmark$ & \\
\hline
\end{tabular}




\begin{tabular}{|l|l|l|l|l|l|}
\hline \multicolumn{2}{|c|}{ Grain } & \multicolumn{5}{|c|}{ Dimensi } \\
\hline & $\begin{array}{l}\text { Jenis } \\
\text { Periz } \\
\text { inan }\end{array}$ & $\begin{array}{c}\text { Pe } \\
\text { mil } \\
\text { ik }\end{array}$ & $\begin{array}{c}\text { Bid } \\
\text { ang } \\
\text { Usa } \\
\text { ha }\end{array}$ & $\begin{array}{c}\text { Wa } \\
\text { ktu }\end{array}$ & $\begin{array}{c}\text { Lok } \\
\text { asi }\end{array}$ \\
\hline $\begin{array}{l}\text { Informasi jumlah } \\
\text { investasi pertahun }\end{array}$ & & & & $\checkmark$ & \\
\hline $\begin{array}{l}\text { Informasi jumlah } \\
\text { investasi berdasarkan } \\
\text { kecamatan jumlah }\end{array}$ & $\checkmark$ & & & & \\
\hline $\begin{array}{l}\text { Informasi berdasarkan } \\
\text { investasi beran } \\
\text { jenis perizinan }\end{array}$ & & & & & \\
\hline
\end{tabular}

Setelah terbentuk pemilihan Grain maka dilakukan identifikasi dan penyesuaian Dimensi. Pada penelitian ini terdapat lima tabel dimensi yaitu dimensi jenis perizinan, pemilik, bidang usaha, waktu, dan dimensi lokasi serta satu tabel fakta yaitu fakta perizinan. Dapat dilihat tabel 2 merupakan identifikasi dari tabel fakta perizinan dan tabel 3 merupakan identifikasi dari salah satu tabel dimensi.

TABEL II FAKTA PERIZINAN

\begin{tabular}{|l|l|l|}
\hline Field Fakta & Fungsi Field & Keterangan \\
\hline $\begin{array}{l}\text { Fakta_perizinan.id } \\
\text { perizinan }\end{array}$ & Primary Key & $\begin{array}{l}\text { Merupakan primary key } \\
\text { dari tabel fakta perizinan }\end{array}$ \\
\hline $\begin{array}{l}\text { Fakta_perizinan.sk } \\
\text { _enisperizinan }\end{array}$ & Foreign Key & $\begin{array}{l}\text { Merupakan primary key } \\
\text { dari tabel dimensi jenis } \\
\text { perizinan }\end{array}$ \\
\hline $\begin{array}{l}\text { Fakta_perizinan.sk } \\
\text { _lokasi }\end{array}$ & Foreign Key & $\begin{array}{l}\text { Merupakan primary key } \\
\text { dari tabel dimensi lokasi }\end{array}$ \\
\hline
\end{tabular}

\begin{tabular}{|l|l|l|}
\hline Field Fakta & Fungsi Field & Keterangan \\
\hline $\begin{array}{l}\text { Fakta_perizinan.sk } \\
\text { _pemilik }\end{array}$ & Foreign Key & $\begin{array}{l}\text { Merupakan primary } \text { key } \\
\text { dari tabel dimensi } \\
\text { pemilik }\end{array}$ \\
\hline $\begin{array}{l}\text { Fakta_perizinan.sk } \\
\text { _bidangusaha }\end{array}$ & Foreigh Key & $\begin{array}{l}\text { Merupakan } \text { primary } \text { key } \\
\text { dari tabel dimensi } \\
\text { bidang usaha }\end{array}$ \\
\hline $\begin{array}{l}\text { Fakta_perizinan.sk } \\
\text { _waktu }\end{array}$ & Foreign Key & $\begin{array}{l}\text { Merupakan primary } \text { key } \\
\text { dari dimensi waktu }\end{array}$ \\
\hline $\begin{array}{l}\text { Fakta } \\
\text { Perizinan.investasi }\end{array}$ & Measurement & $\begin{array}{l}\text { Jumlah Investasi pada } \\
\text { perizinan. }\end{array}$ \\
\hline
\end{tabular}

TABEL III

IDENTIFIKASI DIMENSI

\begin{tabular}{|l|l|}
\hline \multicolumn{1}{|c|}{ Dimensi } & \multicolumn{1}{c|}{ Identifikasi } \\
\hline Jenis perizinan & $\begin{array}{l}\text { Menyimpan informasi jenis perizinan } \\
\text { serta kegiatannya }\end{array}$ \\
\hline Pemilik & Menyimpan informasi pemilik \\
\hline Bidang usaha & Menyimpan informasi bidang usaha \\
\hline Waktu & $\begin{array}{l}\text { Menyimpan informasi keterangan } \\
\text { waktu (tanggal, bulan dan tahun) }\end{array}$ \\
\hline Lokasi & Menyimpan informasi keterangan lokasi \\
\hline
\end{tabular}

Kemudian dilakukan identifikasi dan penyesuaian Dimensi, maka barulah dirancang skema Data Warehouse, yaitu Star Scheme, dimana tabel dimensi secara langsung dihubungkan dengan tabel fakta dan satu tabel fakta harus memiliki minimal hubungan dengan satu tabel dimensi. Rancangan skema Data Warehouse ini dapat dilihat pada gambar 5 .

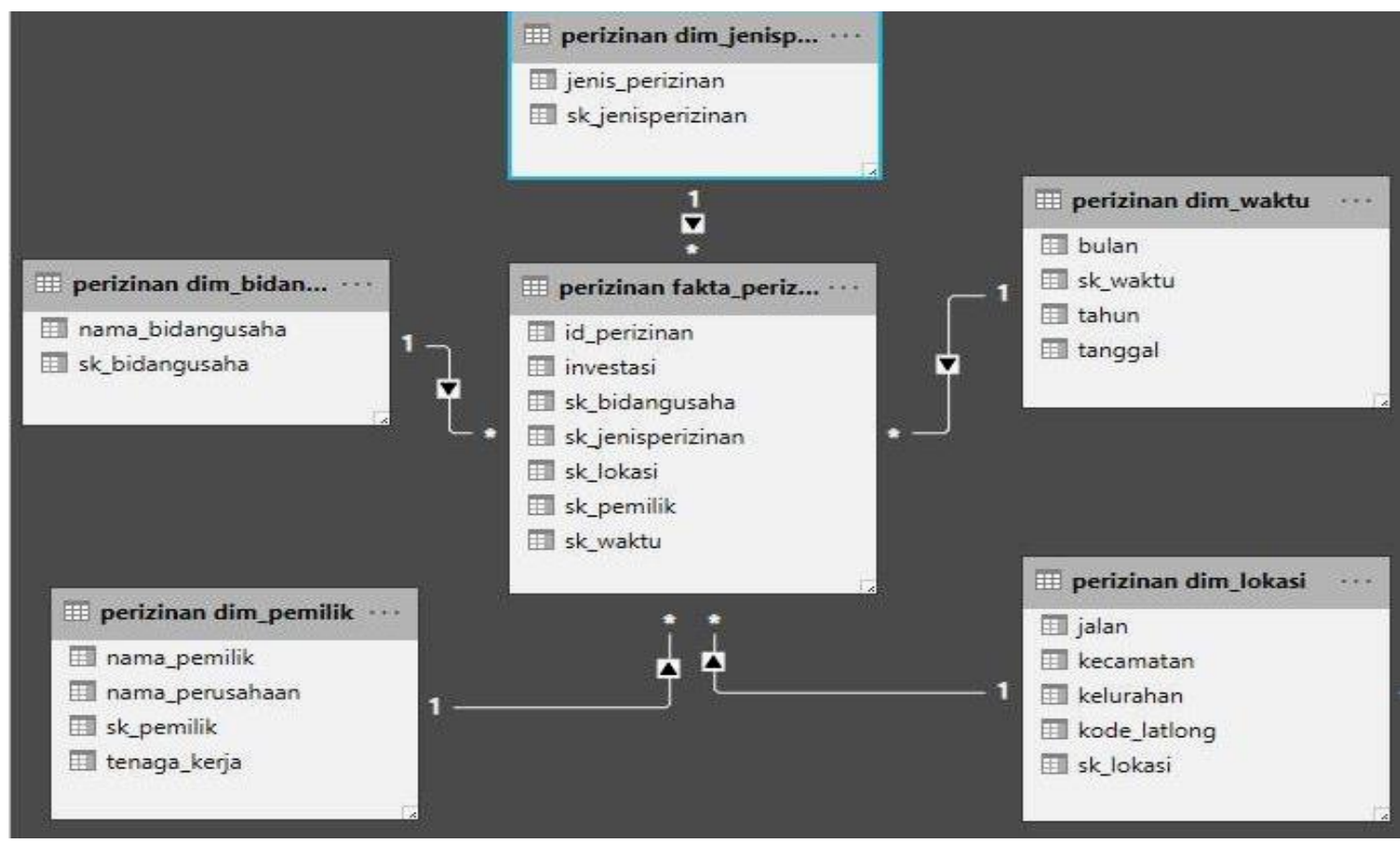

Gambar 5. Star Scheme Data Warehouse 


\section{Proses ETL (Extract Transform Load)}

Pada proses ETL ini digunakan tool Pentaho Data Integration (PDI). Tahapannya adalah dengan melakukan pemindahan data dari data sumber ke database OLAP. Data sumber didapat dari Aplikasi SiCantik yang kemudian dilakukan proses extract menjadi data excel. Selanjutnya dilakukan proses transform data dengan memodfikasi, integrasi dan validasi data yang diperlukan, selanjutnya dilakukan proses load untuk memasukkan data kedalam target akhir yaitu pada Data Warehouse. Database baru dibuat menggunakan MySQL untuk menampung data yang diproses melalui ETL. Database tersebut kemudian dihubungkan dengan PDI untuk dilakukan proses ETL. Proses ETL dilakukan sesuai dengan banyaknya tabel dimensi dan tabel fakta yang sudah dirancang yaitu 5 tabel Dimensi dan 1 tabel fakta. Gambar 6 merupakan salah satu bentuk hasil proses ETL, yaitu ETL table fakta perizinan.

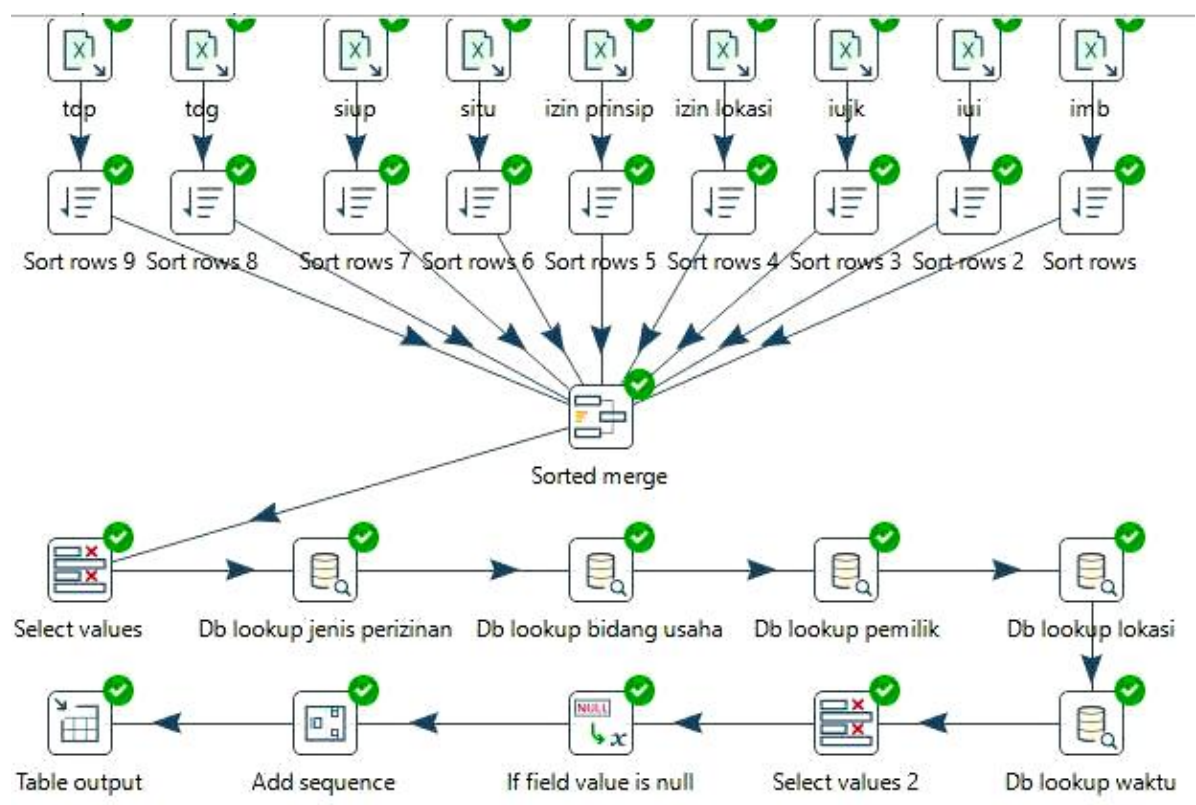

Gambar 6. Proses ETL tabel fakta perizinan

Sementara itu dapat dilihat pada gambar 7 yaitu hasil eksekusi dari proses ETL table Fakta Perizinan.

\begin{tabular}{|c|c|c|c|c|c|c|c|}
\hline \multicolumn{8}{|c|}{ Execution Results } \\
\hline \multicolumn{8}{|c|}{ 目 Logging (9) Execution History $\left.\right|_{2=} ^{1}=$ Step Metrics $1 \mu$ Performance Graph } \\
\hline \multicolumn{8}{|c|}{ First rows $\bigcirc$ Last rows $\bigcirc$ off } \\
\hline$\hat{\#}$ & investasi & sk_jenisperizinan & sk_bidangusaha & sk_pemilik & sk_lokasi & sk_waktu & id_perizinan \\
\hline 1 & 59630000.0 & 1 & 41015 & 3611 & 1 & 50 & 1 \\
\hline 2 & 133500000.0 & 1 & 41016 & 3612 & 1 & 50 & 2 \\
\hline 3 & 59630000.0 & 1 & 41016 & 3613 & 1 & 50 & 3 \\
\hline 4 & 59630000.0 & 1 & 41016 & 3614 & 1 & 50 & 4 \\
\hline 5 & 59630000.0 & 1 & 41015 & 3615 & 1 & 50 & 5 \\
\hline 6 & 1078274223.0 & 1 & 41019 & 3616 & 6 & 995 & 6 \\
\hline 7 & 1061672000.0 & 1 & 41019 & 3616 & 7 & 995 & 7 \\
\hline 8 & 165000000.0 & 1 & 41019 & 3618 & 8 & 68 & 8 \\
\hline 9 & 166500000.0 & 1 & 41019 & 3619 & 1 & 243 & 9 \\
\hline 10 & 196073000.0 & 1 & 41019 & 3620 & 1 & 357 & 10 \\
\hline
\end{tabular}

Gambar 7. Hasil eksekusi proses ETL tabel fakta perizinan

\section{Penerapan Microsoft Power BI}

Microsoft Power BI adalah sebuah aplikasi analitis untuk melakukan proses analisa data. Microsoft Power BI juga merupakan sebuah perangkat lunak yang digunakan untuk merancang visualisasi yang merepresentasikan data pada Data Warehouse [15]. Penerapan Microsoft Power BI terdiri dari beberapa proses, yaitu load data, pembuatan measure, dan visualisasi.
1) Load Data: Tahapan pertama yang dikerjakan yaitu memilih menu Get Data dan Database MySQL untuk mengoneksikan dengan database yang telah dirancang sebelumnya. Proses ini terlihat pada gambar 8 . 


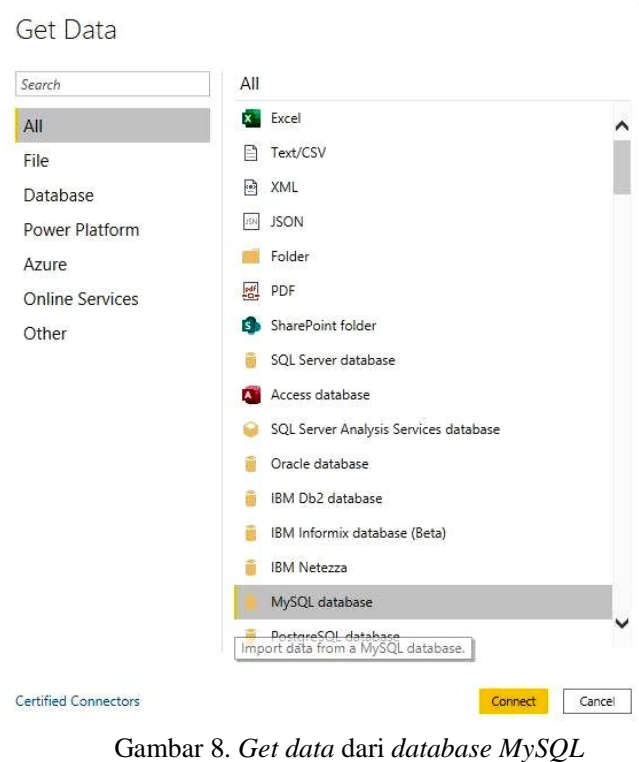

Setelah dilakukan proses Get data source dari Database MySQL, isi nama server dan nama database yang digunakan pada database MySQL, untuk melakukan import data ke Aplikasi Microsoft Power BI. Langkah ini terlihat pada gambar 9 .

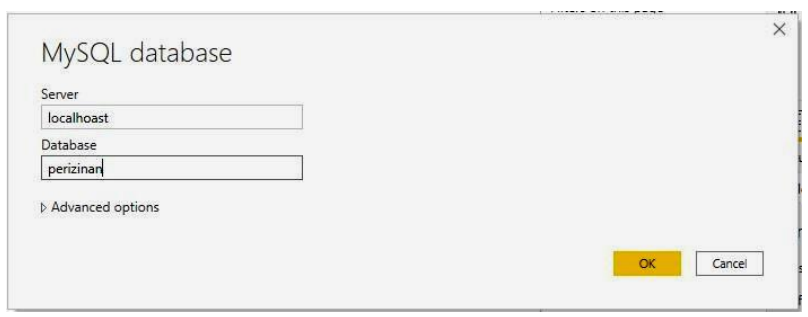

Gambar 9. Konfigusi server dan database untuk import data

Kemudian ditampilkan seluruh data pada Data Warehouse lalu dipilih seluruh data yang akan di-load (dimasukkan) ke Aplikasi Microsoft PowerBI, seperti yang dapat dilihat pada gambar 10.

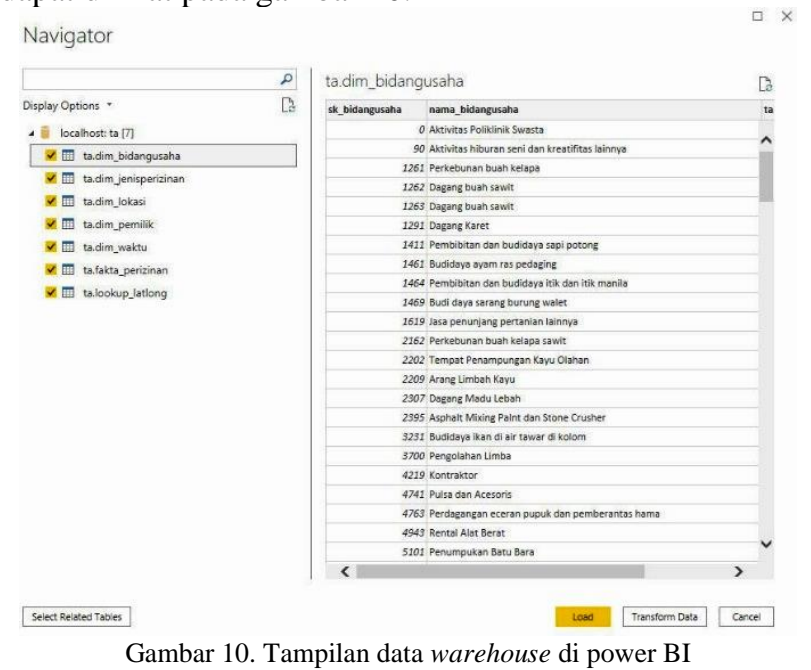

Gambar 10. Tampilan data warehouse di power BI
2) Measure: Tahapan ini bertujuan untuk melakukan manipulasi data. Measure yang digunakan dalam proses perancangan visualisasi data fakta perizinan ini yaitu COUNT, DISTINCTCOUNT dan SUM. COUNT digunakan untuk proses perhitungan jumlah sel dalam kolom yang berisi nilai dan tidak boleh kosong. DISTINCTCOUNT digunakan untuk menghitung jumlah nilai dalam kolom yang berbeda, akan tetapi sel dengan nilai yang sama akan dianggap satu. SUM digunakan untuk menghitung jumlah dari semua nilai yang ada di dalam kolom. Contoh measure pada Fakta Perizinan dapat dilihat seperti pada tabel 4.

TABEL IV

MEASURE PADA FAKTA PERIZINAN

\begin{tabular}{|l|l|}
\hline \multicolumn{1}{|c|}{$\begin{array}{c}\text { Nama } \\
\text { Measure }\end{array}$} & Measure \\
\hline $\begin{array}{l}\text { Total } \\
\text { perizinan }\end{array}$ & = COUNT(fakta_perizinan[id_perizinan]) \\
\hline $\begin{array}{l}\text { Total } \\
\text { perizinan }\end{array}$ & $=$ COUNT(fakta_perizinan[id_perizinan]) \\
\hline $\begin{array}{l}\text { Total } \\
\text { kecamatan }\end{array}$ & $\begin{array}{l}\text { = DISTINCTCOUNT } \\
\text { (fakta_perizinan[sk_lokasi]) }\end{array}$ \\
\hline $\begin{array}{l}\text { Total bidang } \\
\text { usaha }\end{array}$ & $\begin{array}{l}\text { = DISTINCTCOUNT } \\
\text { (fakta_perizinan[sk_bidangusaha]) }\end{array}$ \\
\hline $\begin{array}{l}\text { Total jenis } \\
\text { perizinan }\end{array}$ & $\begin{array}{l}\text { = DISTINCTCOUNT } \\
\text { (fakta_perizinansk[sk_jenisperizinan]) }\end{array}$ \\
\hline $\begin{array}{l}\text { Total } \\
\text { perusahaan }\end{array}$ & $\begin{array}{l}\text { = DISTINCTCOUNT } \\
\text { (fakta_perizinan[sk_pemilik]) }\end{array}$ \\
\hline $\begin{array}{l}\text { Total } \\
\text { investasi }\end{array}$ & =SUM(fakta_perizinan[investasi]) \\
\hline
\end{tabular}

3) Visualisasi: Berfungsi untuk menyajikan data yang detail menjadi informasi yang mudah diterima pengguna [16]. Visualisasi yang digunakan untuk perancangan Dashboard dan Clustering pada Dinas DPMPTSP ini adalah dalam bentuk teks dan grafik. Output dari rancangan visualisasi ini menghasilkan tiga jenis dashboard yaitu dashboard berupa informasi layanan, investasi dan sebaran lokasi perusahaan yang melakukan layanan perizinan pada DPMPTSP Kabupaten Dharmasraya.

\section{a) Dashboard Informasi Layanan Perizinan}

Dashboard informasi layanan perizinan ini berhubungan dengan data layanan perizinan yang ada pada DPMPTSP dari tahun 2016-1018. Dashboard ini berisi informasi total perizinan yang telah diterbitkan, total jenis perizinan, total bidang usaha pada perizinan, total perusahaan yang melakukan perizinan, jumlah perizinan pertahun, jumlah perizinan berdasrkan jenis perizinan, top 10 bidang usaha berdasarkan jumlah perizinan.Dashboard ini ditampilkan menggunakan visualisasi stacked bar chart, pie chart, donut chart, card dan slicer. Dashboard inidapat digunakan untuk mengetahui perkembangan jumlah pelayanan perizinan di DPMPTSP. Berdasarkan gambar 11 dapat di ketahui jumlah perizinan dari tahun 2016-2018 mengalami penurunan. Sementara itu dari Top 10 bidang 
usaha berdasarkan jumlah perizinan "Developer" menempati urutan pertama yaitu sebesar 31,18\%. Untuk Jumlah Perizinan berdasarkan Jenis Perizinannya "SITU" menempati posisi pertama sebesar 33,49\%. Informasi lebih detil mengenai layanan perizinan ini dapat terlihat pada gambar 11 .

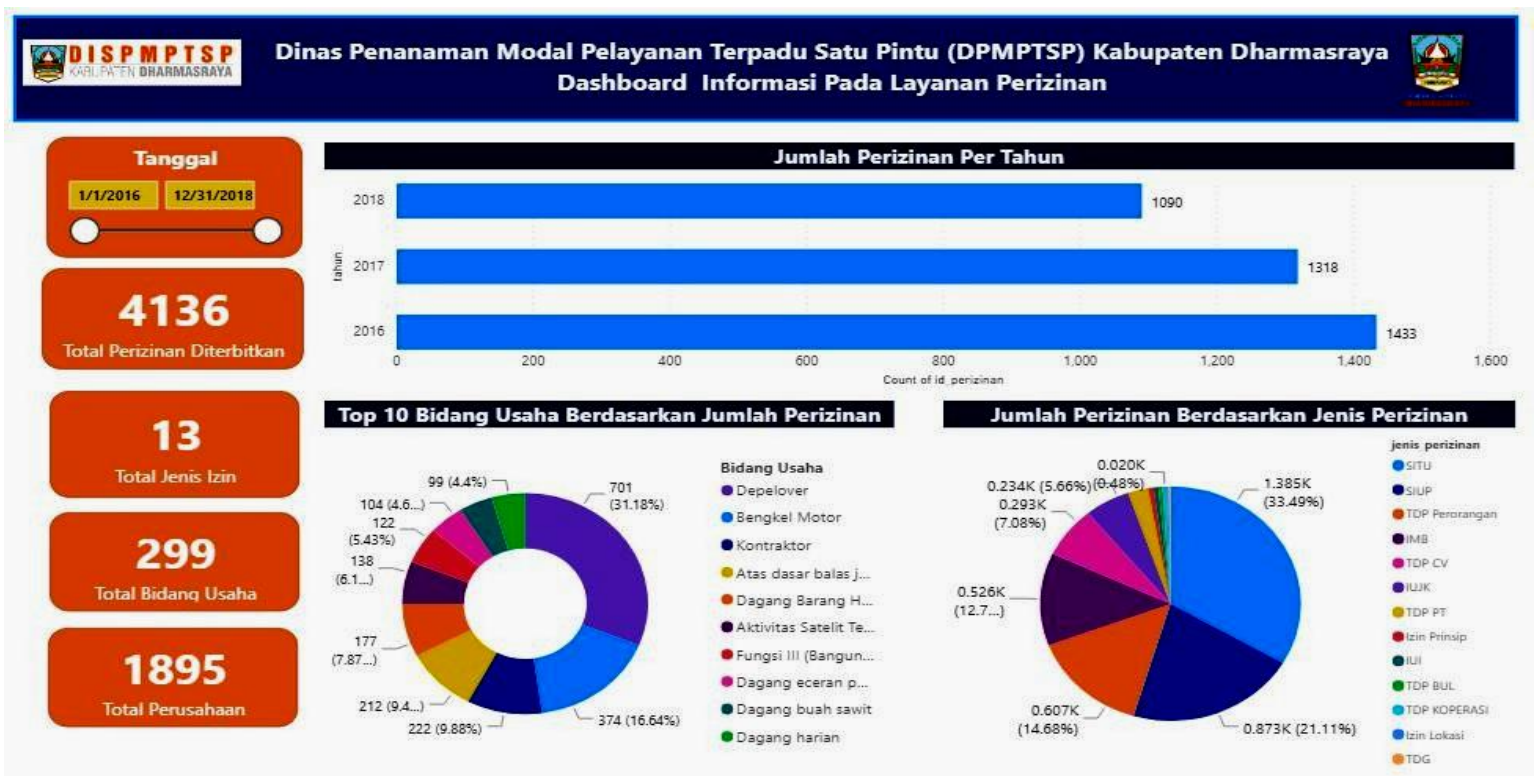

Gambar 11. Dashboard informasi layanan perizinan

\section{b) Dashboard Investasi Pada Layanan Perizinan}

Dashboard investasi pada layanan perizinan ini berhubungan dengan data investasi pada layanan perizinan yang ada di DPMPTSP dari tahun 2016-1018. Dashboard ini berisi informasi total jumlah investasi, jumlah investasi pertahun, jumlah investasi berdasarkan jenis perizinan, jumlah investasi berdasrkan kecamatan dan top 5 investasi terbesar berdasarkan bidang usaha. Dashboard ini ditampilkan menggunakan visalisasi stacked column chart, line chart, pie chart dan card. Berdasarkan gambar 12. Dapat dilihat bahwa jumlah investasi pertahun dari tahun 2016-2018 terus mengalami penurunan. Sementara itu dilihat dari jumlah investasi berdasarkan kecamatan, "Pulau Punjung" menempati posisi pertama yaitu sebesar 44 Triliyun. Untuk 5 Investasi terbesar berdasarkan bidang usaha, "Bengkel Motor" menempati posisi pertama yaitu sebesar 38, 34\%. Melalui Dashboard ini dapat diketahui daerah mana yang bagus untuk investor berinvestasi dan dapat melakukan promosi ke Penanam Modal Dalam Negeri (PMDN) dan Penanam Modal Asing (PMA) serta mengetahui bidang usaha mana yang paling banyak jumlah investasinya. Informasi lebih detil dari Dashboard investasi layanan perizinan ini terlihat pada gambar 12 .

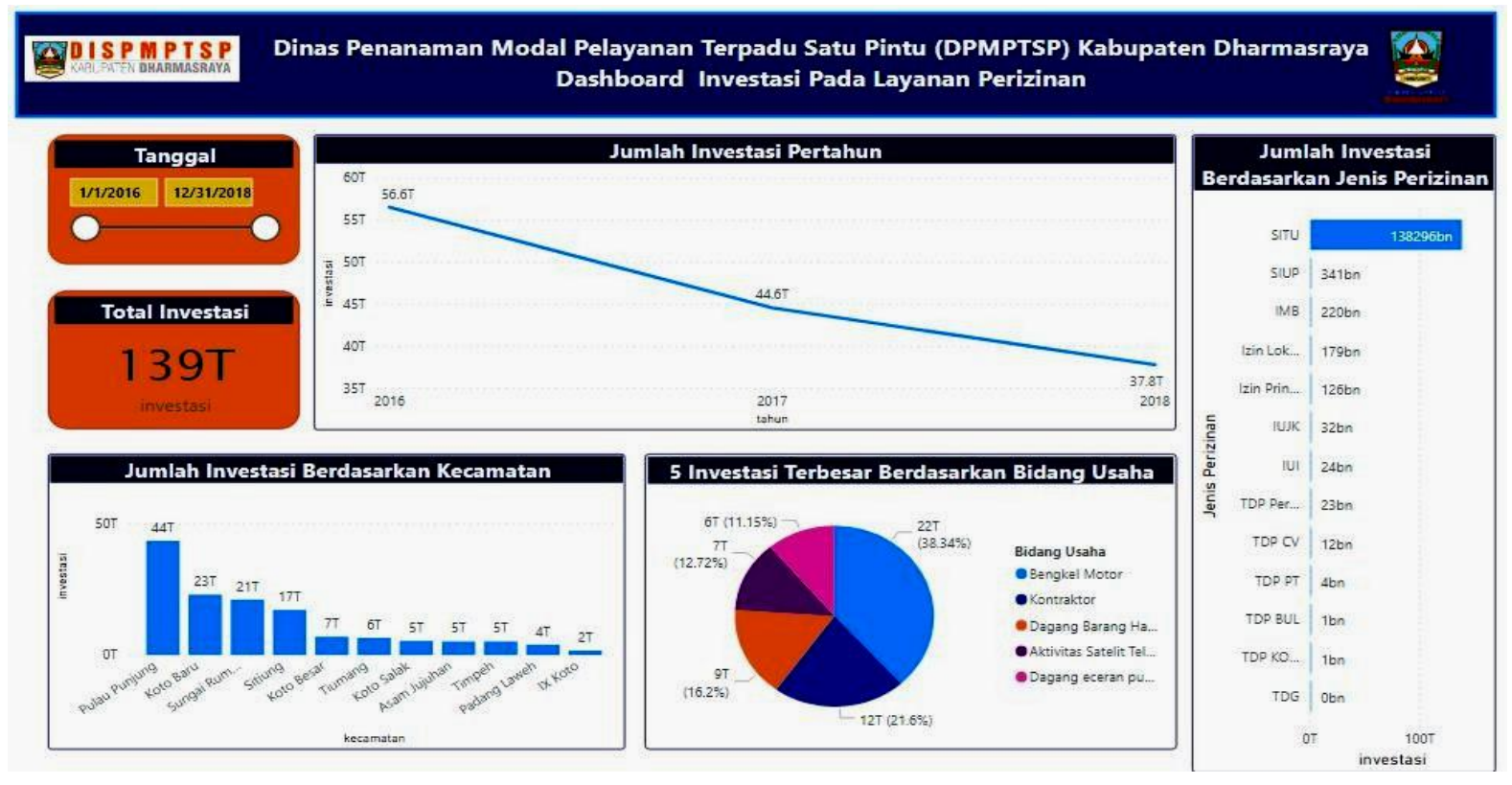

Gambar 12. Dashboard investasi pada layanan perizinan 
c) Dashboard Sebaran Lokasi Perusahaan Pada Layanan Perizinan

Dashboard sebaran lokasi perusahaan pada layanan perizinan ini berhubungan dengan data lokasi pada layanan perizinan yang ada di DPMPTSP dari tahun 2016-1018. Dashboard ini berisi informasi jumlah kecamatan, peta sebaran jumlah perizinan berdasarkan kecamatan, jumlah perizinan per kecamatan, jumlah perizinan per kecamatan berdasarkan jenis perizinan dan top 5 kecamatan berdasarkan jumlah perizinan. Dashboard iniditampilkan menggunakan visalisasi stacked column chart, map, bubble chart, power KPI 2.0.0 dan card. Dashboard ini dapat digunakan untuk mengetahui di daerah mana masyarakat banyak membuka bidang usaha dan daerah mana yang sedikit membuka bidang usaha, sehingga didapatkan informasi daerah mana yang perlu ditingkatkan investasinya agar terjadinya pemerataan ekonomi dan pemerataan pembangunan ekonomi masyarakat di daerah tersebut yang dapat membuka banyak lowongan pekerjaan sehingga dapa mengurai pengangguran. Dashboard Sebaran Lokasi Perusahaan Pada Layanan Perizinan dapat dilihat pada gambar 13 .

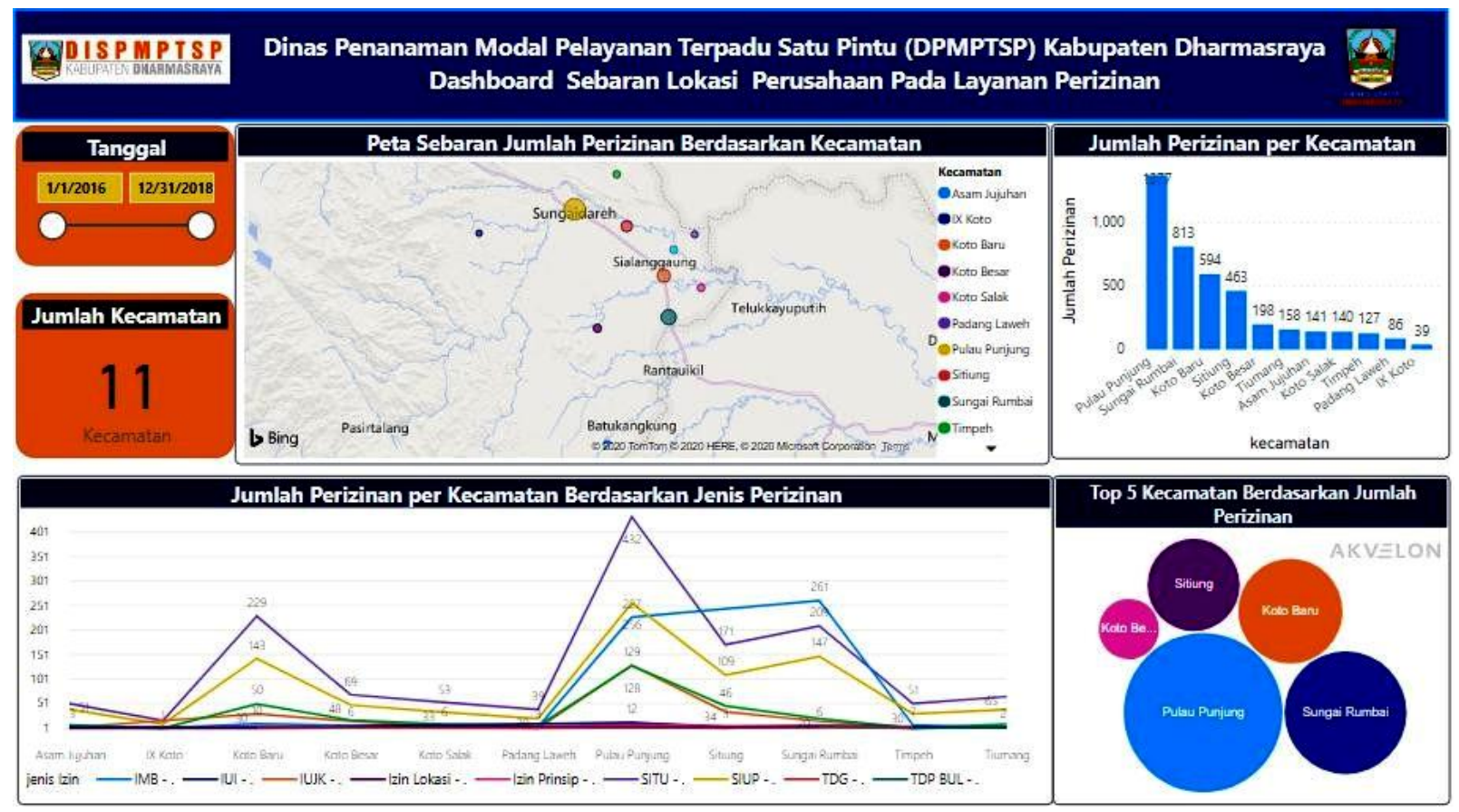

Gambar 13. Dashboard sebaran lokasi perusahaan pada layanan perizinan

\section{d) Visualisasi Clustering}

Clustering atau klasterisasi adalah "suatu proses untuk mengelompokan data ke dalam beberapa cluster atau kelompok sehingga data dalam satu cluster memiliki tingkat kemiripan yang maksimum dan data antar cluster memiliki kemiripan yang minimum" [17].

Algoritma clustering yang terdapat pada Microsoft Power BI ada dua jenis yaitu Expectation Maximization (EM Clustering) dan Clustering K-Means. Untuk EM Clustering, algoritma secara iteratif menyempurnakan model cluster awal agar sesuai dengan data, dan menentukan probabilitas bahwa titik data ada dalam cluster. Sementara Clustering K-Means, menetapkan keanggotaan cluster dengan meminimalkan perbedaan antar item dalam sebuah cluster sambil memaksimalkan jarak antar cluster [11]. Visualisasi Clustering pada penelitian ini dilakukan untuk mengelompokkan data investasi dari 2016 sampai 2018 yaitu data bidang usaha dan data sebaran kecamatan yang terdapat pada data perizinan DPMPTSP. Data tersebut dibagi menjadi tiga cluster, dimana data yang dikelompokkan dalam satu claster tersebut memiliki kemiripan.
Pada dashboard clustering ini terdapat dua visualisasi clustering yaitu pertama clustering data investasi pada kecamatan yang akan dibagi menjadi tiga cluster dengan tingkat investasi besar, sedang dan kecil, hal ini bertujuan agar mengetahui kecamatan mana yang mempunyai tingkat investasi yang baik dan kecamatan mana yang masih kurang tingkat investasinya, sehingga pihak promosi akan lebih mudah mengetahui kecamatan mana yang perlu digencarkan promosinya, serta memberi pemahaman kepada masyarakat begitu pentingnya investasi untuk pemulihan ekonomi daerah dan menciptakan lapangan kerja bagi tenaga kerja lokal. Kedua clustering data investasi pada bidang usaha juga dibagi menjadi tiga cluster yaitu dengan tingkat investasi banyak, sedang dan sedikit, dengan demikian akan diketahui bidang usaha apa yang menghasilkan investasi yang banyak. Hal tersebut akan membantu pihak promosi dalam meningkatkan iklim investasi dengan melakukan promosi bidang usaha tersebut dengan daerah yang masih sedikit tingkat investasinya kepada PMA dan PMDN agar terciptanya pertumbuhan ekonomi yang merata di setiap kecamatan pada Kabupaten Dharmasraya. Serta dapat membantu pihak bidang 
perencanaan dan penanaman modal dalam melaksanakan tugasnya yaitu menyusun data informasi mengenai daya tarik atau profil peluang investasi atau produk unggulan daerah, visualisasi clustering ini juga dapat menjadi acuan dalam menyusun Rencana Kerja (Renja) dan sebagai alat evaluasi pada setiap akhir tahun anggaran. Dashboard clustering dapat dilihat pada Gambar 14.

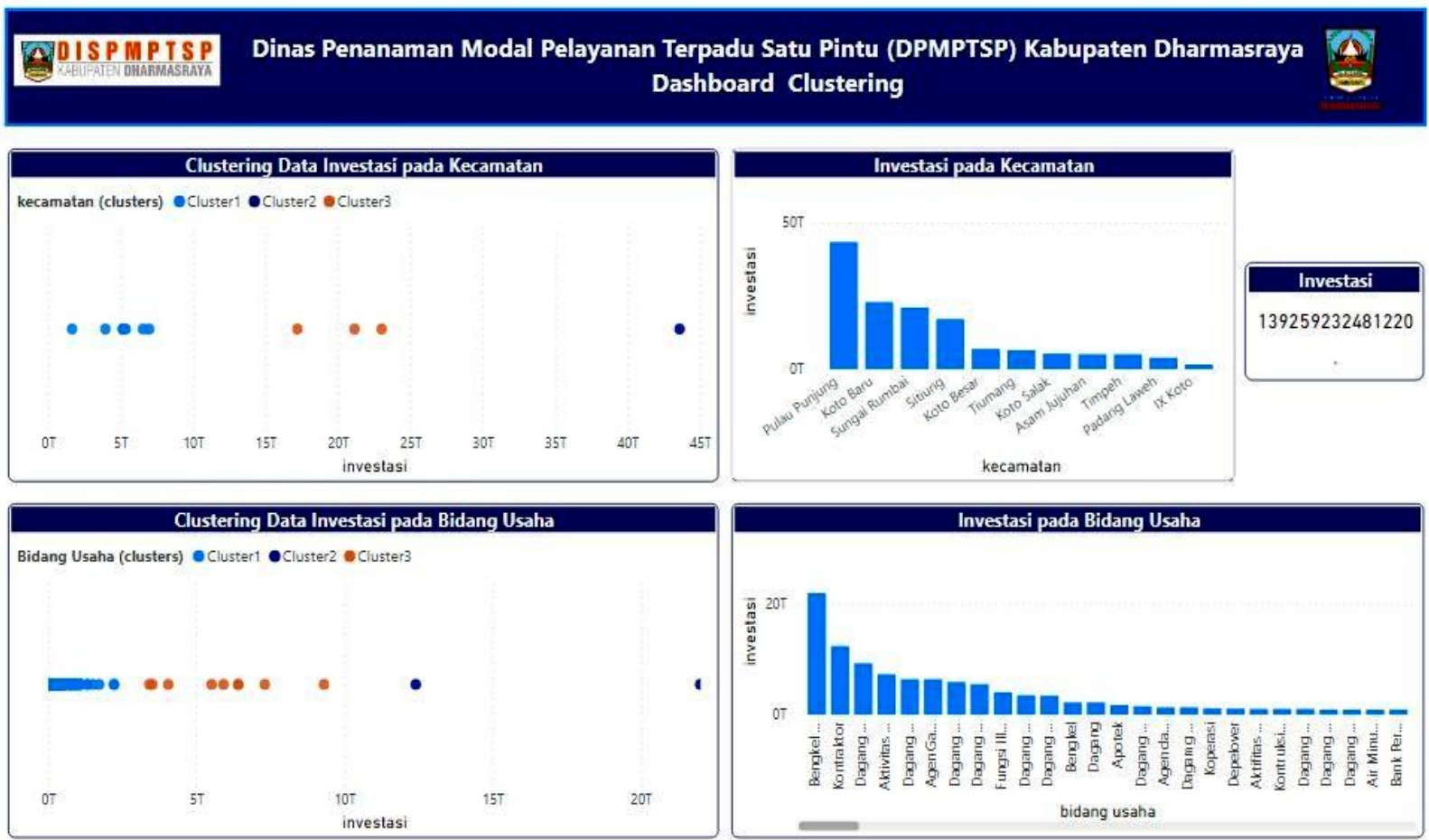

Gambar 14. Dashboard clustering visualization

\section{E. User Acceptance Test (UAT)}

User Acceptance Testing (UAT) adalah tahap testing terakhir dan terpenting dari tahapan testing software yang umum dilakukan. Dalam tahapan ini, pengujian sistem dilakukan untuk menentukan apakah sistem telah memenuhi kebutuhan pengguna dan dapat mendukung semua skenario bisnis dan pengguna. UAT dilakukan oleh client dan end-user [18]. Setelah semua Dashboard dan proses Clustering selesai dirancang, maka sebelum digunakan oleh DPMPTSP Dharmasraya dilakukan dulu pengujian berupa UAT kepada user yang akan menggunakan Dashboard ini. Pengujian dilakukan oleh beberapa orang pengguna Dashboard. Pelaksanaan teknis dari pengujian ini yaitu dengan memperlihatkan serta mencobakan rancangan Dashboard dan Clustering Data oleh user berdasarkan daftar fungsional yang sudah di buat sebelumnya sebagai acuan dari pengujian. Kemudian dilakukan pengecekan kesamaan terhadap uji coba dengan daftar fungsional. Pada penelitian ini semua fitur yang di uji cobakan sudah sesuai dengan daftar fungsional ada. Namun ada beberapa saran dari user diantaranya perlu dibuatkan buku panduan dalam pengelolaan Dashboard. Dokumen UAT ini dapat dilihat pada gambar 15.

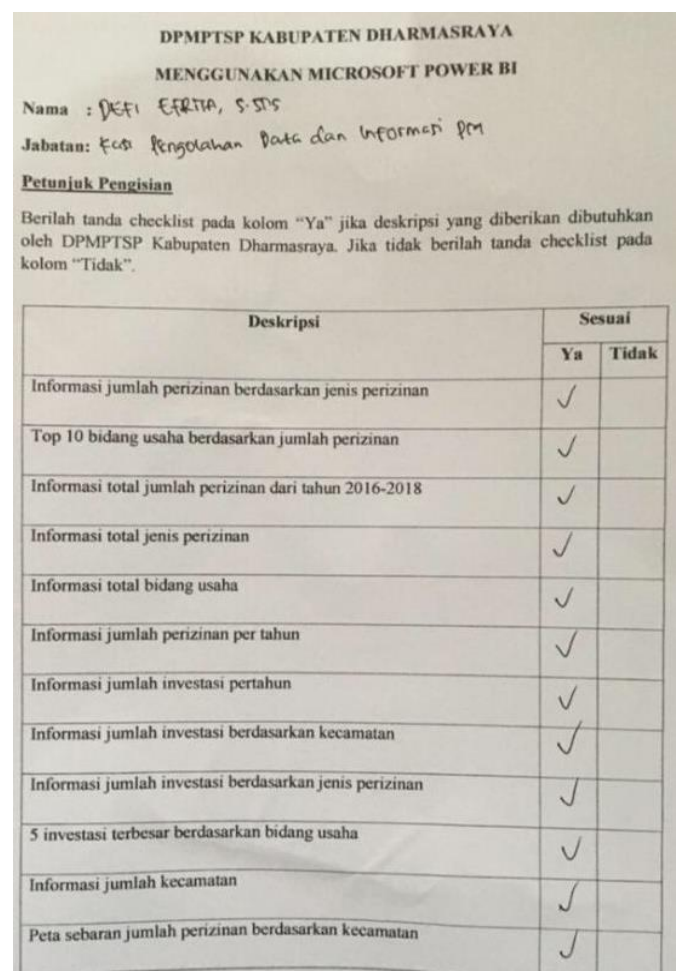

Gambar 15. Dokumen UAT 


\section{KESIMPULAN}

Perancangan Dashboard dan Visualiasasi dengan menerapkan Business Intelligence pada Dinas DPMPTSP telah berhasil dilakukan melalui beberapa tahapan yaitu; 1). Melakukan Rancangan Data Warehouse terhadap data pelayanan perizinan DPMPTSP Kabupaten Dharmasraya dengan menghasilkan lima dimensi yaitu dimensi jenis perizinan, dimensi bidang usaha, dimensi pemilik, dimensi waktu, dan dimensi lokasi, serta satu tabel fakta yaitu fakta perizinan, 2). Proses ETL (Extract, Transform, and Load) dalam membangun Data Warehouse menggunakan Pentaho Data Integration (PDI) sedangkan dalam pembuatan Visualisasi Dashboard menggunakan Microsoft Power BI, 3). Perancangan ini menghasilkan empat dashboard yaitu dashboard informasi layanan perizinan, dashboard informasi investasi pada layanan perizinan, dashboard informasi sebaran lokasi perusahaan pada layanan perizinan dan dashboard clustering, 4). Penerapan Business Intelligence untuk Visualisasi Dashboard ini sudah dapat diimplementasikan oleh DPMPTSP Kabupaten Dharmasraya untuk membantu dalam kepentingan analisis dan pengambilan keputusan.

\section{UCAPAN TERIMA KASIH / ACKNOWLEDGMENT}

Penelitian ini di dukung sepenuhnya oleh Fakultas Teknologi Informasi Universitas Andalas, Padang, Sumatera Barat untuk Publikasi.

\section{REFERENSI}

[1] E. Urmilasari, A. M. Rusli, and A. L. Irwan, "Analisis Pelayanan Perizinan di Badan Perizinan Terpadu danPenanaman Modal Kota Makassar", Jurnal Ilmu Pemerintahan, 6(1), 49-60, 2013

[2] Kabupaten Dharmasraya, Peraturan Daerah tentang Dinas Penanaman Modal Pelayanan Satu Pintu No 20, 2017

[3] R. Akbar, D. Rasyiddah, M. Anrisya, dkk, "Penerapan Aplikasi Power Business Intelligence dalam Menganalisis Prioritas Pekerjaan di Indonesia", Jurnal JEPIN, Vol. 4, No. 1, 2018

[4] R. Akbar, V. Alfarizi, T. Bayu, dkk, "Implementasi Business Intelligence untuk Mendapatkan Pola Penerbangan Penumpang Pesawat dari atau ke Bandara Internasional Minang Kabau". Jurnal JEPIN, Vol. 4 No. 1,2018

[5] A. Zikri, J. Adrian, A. Soniawan, R. Azim, R. Dinur, and R. Akbar, "Implementasi Business Intelligence untuk Menganalisis Data Persalinan Anak di Klinik Ani Padang dengan Menggunakan Aplikasi Tableau Public", Jurnal Online Informatika, 2(1), 20, 2017

[6] D. Pareek, "Business Intelligence For Telecommunication", CRC Press, 2006

[7] Rezkiani, R. E. Indrajit, and M. Fauzy, "Implementasi Konsep Business Intelligence dalam Strategi Pemasaran Public Training Pada PT Zigot Mediatama", Prosiding Seminar Nasional Sains \& Teknologi, Fak. Teknik Muhammdiyah Jakarta, PP 1-9, 2017

[8] H. Ganesha, "Perancangan Data Warehouse untuk Kebutuhan Sistem Penunjang Keputusan Divisi Revenue Assurance Studi Kasus: PT. XXX", InfoTekJar (Jurnal Nasional Informatika dan Teknologi Jaringan), Vol. 3 No. 1, 2018.
[9] R. Vincent, "Building a Data Warehouse: With Examples in SQL Server". New York: A Press, 2008.

[10] WH. Inman, "Building The Data Warehouse Fourth Edition". New York : John Wiley \& Sons, Inc, 2005.

[11] (2021). The Microsoft Website. [Online]. Available : https://docs.microsoft.com/en-us/analysis-services/data mining/microsoft-clustering-algorithm-technicalreference?view=asallproducts-allversions

[12] L.T. Moss and S. Atre, "BI Roadmap: The Complete Project Life Style For Decision Support Application", Bostom, MA. Addison Wesley, 2013

[13] R. Kimball, Margy, T. Warren, M. Joy and B. Bob, "The Data Warehouse Lifecycle Toolkit". Canada: Wiley Publishing, 2008.

[14] A. Dahlan, E. Utami, E.T. Luthfi, "Perancangan Data Warehouse Perpustakaan Perguruan Tinggi XYZ Menggunakan Metode Snowflake Schemall”. RESPATI, Jurnal Teknologi Informasi, Vol VIII No. 24, ISSN : 1907-2430, 2013.

[15] R. Darman, "Analisis Visualisasi dan Pemetaan Data Tanaman Padi di Indonesia Menggunakan Microsoft Power BI" . Jurnal Rekayasa dan Manajemen Sistem Informasi, 4(2), 156-162, 2018.

[16] D. Aryanti, and J. Setiawan, "Visualisasi Data Penjualan dan Produksi PT Nitto Alam Indonesia Periode 2014-2018”. Ultima InfoSys, 2019.

[17] M. Cavallo, and C. Demiralp, "Clustrophile 2 Guided clustering visualization Analysis". IEEE Transactions on Visualization and Computer Graphics, 2018.

[18] (2020). SIS Binus Website. [Online]. Available : https://sis.binus.ac.id/2020/10/28/user-acceptance-test/ 